\title{
FINAL ACT OF THE PARIS CONFERENCE ON CAMBODIA, PARIS 23 OCTOBER 1991*
}

1. Concerned by the tragic conflict and continuing bloodshed in Cambodia, the Paris Conference on Cambodia was convened, at the invitation of the Government of the French Republic, in order to achieve an internationally guaranteed comprehensive settlement which would restore peace to that country. The Conference was held in two sessions, the first from 30 July to 30 August 1989, and the second from 21 to 23 October 1991.

3. The following States participated in the Conference: Australia, Brunei Darussalam, Cambodia, Canada, the People's Republic of China, the French Republic, the Republic of India, the Republic of Indonesia, Japan, the Lao People's Democratic Republic, Malaysia, the Republic of the Philippines, the Republic of Singapore, the Kingdom of Thailand, the Union of Soviet Socialist Republics, the United Kingdom of Great Britain and Northern Ireland, the United States of America and the Socialist Republic of Vietnam.

In addition, the Non-Aligned Movement was represented at the Conference by its current Chairman at each session, namely Zimbabwe at the first session and Yugoslavia at the second session.

4. At the first session of the Conference, Cambodia was represented by the four Cambodian Parties. The Supreme National Council of Cambodia, under the leadership of its President, H.R.H. Prince NORODOM SiHANOUK, represented Cambodia at the second session of the Conference.

\footnotetext{
* Text from UN Doc. A/46/608 or S/23177 of 30 October 1991; only the relevant sections are reproduced.
}

Ko Swan Sik et al. (eds.), Asian Yearbook of International Law, 389-416.

(C) 1993 Kluwer Academic Publishers. Printed in the Netherlands. 
10. At the second session, the Conference adopted the following instruments:

1. AGREEMENT ON A COMPREHENSIVE POLITICAL SETTLEMENT OF THE CAMBODIA CONFLICT, with annexes on the mandate for UNTAC, military matters, elections, repatriation of Cambodian refugees and displaced persons, and the principles for a new Cambodian constitution;

2. AGREEMENT CONCERNING THE SOVEREIGNTY, INDEPENDENCE, TERRITORIAL INTEGRITY AND INVIOLABILITY, NEUTRALITY AND NATIONAL UNITY OF CAMBODIA; and

\section{DECLARATION ON THE REHABILITATION AND RECONSTRUCTION OF CAMBODIA.}

These instruments represent an elaboration of the "Framework for a Comprehensive Political Settlement of the Cambodia Conflict" adopted by the five permanent members of the United Nations Security Council on 28 August 1990, and of elements of the work accomplished at the first session of the Conference.

11. On behalf of Cambodia, the instruments will be signed by the twelve members of the Supreme National Council of Cambodia, which is the unique legitimate body and source of authority enshrining the sovereignty, independence and unity of Cambodia.

\section{II - AGREEMENT ON A COMPREHENSIVE POLITICAL SETTLEMENT OF THE CAMBODIA CONFLICT, PARIS 23 OCTOBER 1991}

The States participating in the Paris Conference on Cambodia, namely Australia, Brunei Darussalam, Cambodia, Canada, the People's Republic of China, the French Republic, the Republic of India, the Republic of Indonesia, Japan, the Lao People's Democratic Republic, Malaysia, the Republic of the Philippines, the Republic of Singapore, the Kingdom of Thailand, the Union of Soviet Socialist Republics, the United Kingdom of Great Britain and Northern Ireland, the United States of America, the Socialist Republic of Vietnam and the Socialist Federal Republic of Yugoslavia,

In the presence of the Secretary-General of the United Nations,

In order to maintain, preserve and defend the sovereignty, independence, territorial integrity and inviolability, neutrality and national unity of Cambodia,

Desiring to restore and maintain peace in Cambodia, to promote national reconciliation and to ensure the exercise of the right to self-determination of the Cambodian people through free and fair elections,

Convinced that only a comprehensive political settlement to the Cambodia conflict will be just and durable and will contribute to regional and international peace and security,

Welcoming the Framework document of 28 August 1990, which was accepted by the Cambodian Parties in its entirety as the basis for settling the Cambodia conflict, and which was subsequently unanimously endorsed by Security Council resolution 668 (1990) of 20 September 1990 and General Assembly resolution 45/3 of 15 October 1990 , 
Noting the formation in Jakarta on 10 September 1990 of the Supreme National Council of Cambodia as the unique legitimate body and source of authority in Cambodia in which, throughout the transitional period, national sovereignty and unity are enshrined, and which represents Cambodia externally,

Welcoming the unanimous election, in Beijing on 17 July 1991, of H.R.H. Prince NORODOM SIHANOUK as the President of the Supreme National Council,

Recognizing that an enhanced United Nations role requires the establishment of a United Nations Transitional Authority in Cambodia (UNTAC) with civilian and military components, which will act with full respect for the national sovereignty of Cambodia,

Noting the statements made at the conclusion of the meetings held in Jakarta on 9-10 September 1990, in Paris on 21-23 December 1990, in Pattaya on 24-26 June 1991, in Beijing on 16-17 July 1991, in Pattaya on 26-29 August 1991, and also the meetings held in Jakarta on 4-6 June 1991 and in New-York on 19 September 1991,

Welcoming United Nations Security Council resolution 717 (1991) of 16 October 1991 on Cambodia,

Recognizing that Cambodia's tragic recent history requires special measures to assure protection of human rights, and the non-return to the policies and practices of the past,

Have agreed as follows:

\title{
PART I
}

\section{ARRANGEMENTS DURING THE TRANSITIONAL PERIOD}

\author{
Section I \\ Transitional Period
}

Article 1

For the purposes of this Agreement, the transitional period shall commence with the entry into force of this Agreement and terminate when the constituent assembly elected through free and fair elections, organized and certified by the United Nations, has approved the constitution and transformed itself into a legislative assembly, and thereafter a new government has been created.

\section{Section II \\ United Nations Transitional Authority in Cambodia}

\section{Article 2}

(1) The Signatories invite the United Nations Security Council to establish a United Nations Transitional Authority in Cambodia (hereinafter referred to as "UNTAC") with civilian and military components under the direct responsibility of the SecretaryGeneral of the United Nations. For this purpose the Secretary-General will designate a Special Representative to act on his behalf. 
(2) The Signatories further invite the United Nations Security Council to provide UNTAC with the mandate set forth in this Agreement and to keep its implementation under continuing review through periodic reports submitted by the Secretary-General.

\section{Section III \\ Supreme National Council}

\section{Article 3}

The Supreme National council (hereinafter referred to as "the SNC") is the unique legitimate body and source of authority in which, throughout the transitional period, the sovereignty, independence and unity of Cambodia are enshrined.

\section{Article 4}

The members of the SNC shall be committed to the holding of free and fair elections organized and conducted by the United Nations as the basis for forming a new and legitimate Government.

\section{Article 5}

The SNC shall, throughout the transitional period, represent Cambodia externally and occupy the seat of Cambodia at the United Nations, in the United Nations specialized agencies, and in other international institutions and international conferences.

\section{Article 6}

The SNC hereby delegates to the United Nations all powers necessary to ensure the implementation of this Agreement, as described in annex 1.

In order to ensure a neutral political environment conducive to free and fair general elections, administrative agencies, bodies and offices which could directly influence the outcome of elections will be placed under direct United Nations supervision or control. In that context, special attention will be given to foreign affairs, national defence, finance, public security and information. To reflect the importance of these subjects, UNTAC needs to exercise such control as is necessary to ensure the strict neutrality of the bodies responsible for them. The United Nations, in consultation with the SNC, will identify which agencies, bodies and offices could continue to operate in order to ensure normal day-to-day life in the country.

\section{Article 7}

The relationship between the SNC, UNTAC and existing administrative structures is set forth in annex 1. 


\section{Section IV \\ Withdrawal of foreign forces and its verification}

\section{Article 8}

Immediately upon entry into force of this Agreement, any foreign forces, advisers, and military personnel remaining in Cambodia, together with their weapons, ammunition, and equipment, shall be withdrawn from Cambodia and not be returned. Such withdrawal and non-return will be subject to UNTAC verification in accordance with annex 2.

\section{Section V \\ Cease-fire and cessation of outside military assistance}

\section{Article 9}

The cease-fire shall take effect at the time this Agreement enters into force. All forces shall immediately disengage and refrain from all hostilities and from any deployment, movement or action which would extend the territory they control or which might lead to renewed fighting.

The Signatories hereby invite the security Council of the United Nations to request the Secretary-General to provide good offices to assist in this process until such time as the military component of UNTAC is in position to supervise, monitor and verify it.

\section{Article 10}

Upon entry into force of this Agreement, there shall be an immediate cessation of all outside military assistance to all Cambodian Parties.

\section{Article 11}

The objectives of military arrangements during the transitional period shall be to stabilize the security situation and build confidence among the parties to the conflict, so as to reinforce the purposes of this Agreement and to prevent the risks of a return to warfare.

Detailed provisions regarding UNTAC's supervision, monitoring, and verification of the cease-fire and related measures, including verification of the withdrawal of foreign forces and the regrouping, cantonment and ultimate disposition of all Cambodian forces and their weapons during the transitional period are set forth in annex 1 , section $\mathrm{C}$, and annex 2 .

\section{PART II}

\section{ELECTIONS}

\section{Article 12}

The Cambodian people shall have the right to determine their own political future 
through the free and fair election of a constituent assembly, which will draft and approve a new Cambodian Constitution in accordance with Article 23 and transform itself into a legislative assembly, which will create the new Cambodian Government. This election will be held under United Nations auspices in a neutral political environment with full respect for the national sovereignty of Cambodia.

\section{Article 13}

UNTAC shall be responsible for the organization and conduct of these elections based on the provisions of annex 1 , section $\mathrm{D}$, and annex 3 .

\section{Article 14}

All Signatories commit themselves to respect the results of these elections once certified as free and fair by the United Nations.

\section{PART III}

\section{HUMAN RIGHTS}

\section{Article 15}

1. All persons in Cambodia and all Cambodian refugees and displaced persons shall enjoy the rights and freedoms embodied in the Universal Declaration of Human Rights and other relevant international human rights instruments.

2. To this end,

(a) Cambodia undertakes:

- to ensure respect for and observance of human rights and fundamental freedoms in Cambodia;

- to support the right of all Cambodian citizens to undertake activities which would promote and protect human rights and fundamental freedoms;

- to take effective measures to ensure that the policies and practices of the past shall never be allowed to return;

- to adhere to relevant international human rights instruments;

(b) the other Signatories to this Agreement undertake to promote and encourage respect for and observance of human rights and fundamental freedoms in Cambodia as embodied in the relevant international instruments and the relevant resolutions of the United Nations General Assembly, in order, in particular, to prevent the recurrence of human rights abuses.

Article 16

UNTAC shall be responsible during the transitional period for fostering an environment in which respect for human rights shall be ensured, based on the provisions of annex 1, section $\mathrm{E}$. 


\section{Article 17}

After the end of the transitional period, the United Nations Commission on Human Rights should continue to monitor closely the human rights situation in Cambodia, including, if necessary, by the appointment of a Special Rapporteur who would report his findings annually to the Commission and to the General Assembly.

\section{PART IV}

\section{INTERNATIONAL GUARANTEES}

\section{Article 18}

Cambodia undertakes to maintain, preserve and defend, and the other Signatories undertake to recognize and respect, the sovereignty, independence, territorial integrity and inviolability, neutrality and national unity of Cambodia, as set forth in a separate Agreement.

\section{PART V \\ REFUGEES AND DISPLACED PERSONS}

Article 19

Upon entry into force of this Agreement, every effort will be made to create in Cambodia political, economic and social conditions conducive to the voluntary return and harmonious integration of Cambodian refugees and displaced persons.

Article 20

(1) Cambodian refugees and displaced persons, located outside Cambodia, shall have the right to return to Cambodia and to live in safety, security and dignity, free from intimidation or coercion of any kind.

(2) The Signatories request the Secretary-General of the United Nations to facilitate the repatriation in safety and dignity of Cambodian refugees and displaced persons, as an integral part of the comprehensive political settlement and under the overall authority of the Special Representative of the Secretary-General, in accordance with the guidelines and principles on the repatriation of refugees and displaced persons as set forth in annex 4. 


\section{PART VI \\ RELEASE OF PRISONERS OF WAR AND CIVILIAN INTERNEES}

Article 21

The release off all prisoners off war and civilian internees shall be accomplished at the earliest possible date under the direction of the International Committee of the Red Cross (ICRC) in co-ordination with the Special Representative of the Secretary-General, with the assistance, as necessary, of other appropriate international humanitarian organizations and the Signatories.

\section{Article 22}

The expression "civilian internees" refers to all persons who are not prisoners of war and who, having contributed in any way whatsoever to the armed or political struggle, have been arrested or detained by any of the parties by virtue of their contribution thereto.

\section{PART VII}

\section{PRINCIPLES FOR A NEW CONSTITUTION FOR CAMBODIA}

\section{Article 23}

Basic principles, including those regarding human rights and fundamental freedoms as well as regarding Cambodia's status of neutrality, which the new Cambodian Constitution will incorporate, are set forth in annex 5 .

\section{PART VIII}

\section{REHABILITATION AND RECONSTRUCTION}

\section{Article 24}

The Signatories urge the international community to provide economic and financial support for the rehabilitation and reconstruction of Cambodia, as provided in a separate declaration.

\section{PART IX}

\section{FINAL PROVISIONS}

\section{Article 25}

The Signatories shall, in good faith and in a spirit of co-operation, resolve through peaceful means any disputes with respect to the implementation of this Agreement. 


\section{Article 26}

The signatories request other States, international organizations and other bodies to co-operate and assist in the implementation of this Agreement and in the fulfilment by UNTAC of its mandate.

\section{Article 27}

The Signatories shall provide their full co-operation to the United Nations to ensure the implementation of its mandate, including by the provision of privileges and immunities, and by facilitating freedom of movement and communication within and through their respective territories.

In carrying out its mandate, UNTAC shall exercise due respect for the sovereignty of all States neighbouring Cambodia.

\section{Article 28}

(1) The Signatories shall comply in good faith with all obligations undertaken in this Agreement and shall extend full co-operation to the United Nations, including the provision of the information which UNTAC requires in the fulfilment of its mandate.

(2) The signature on behalf of Cambodia by the members of the SNC shall commit all Cambodian parties and armed forces to the provisions of this Agreement.

\section{Article 29}

Without prejudice to the prerogatives of the Security Council of the United Nations, and upon the request of the Secretary-General, the two Co-Chairmen of the Paris Conference on Cambodia, in the event of a violation or threat of violation of this Agreement, will immediately undertake appropriate consultations, including with members of the Paris Conference on Cambodia, with a view to taking appropriate steps to ensure respect for these commitments.

\section{Article 30}

This Agreement shall enter into force upon signature.

\section{Article 31}

This Agreement shall remain open for accession by all States. The instruments of accession shall be deposited with the Governments of the French Republic and the Republic of Indonesia. For each State acceding to the Agreement it shall enter into force on the date of deposit of its instruments of accession. Acceding States shall be bound by the same obligations as the Signatories.

\section{Article 32}

The originals of this Agreement, of which the Chinese, English, French, Khmer and 
Russian texts are equally authentic, shall be deposited with the Governments of the French Republic and the Republic of Indonesia, which shall transmit certified true copies to the Governments of the other States participating in the Paris Conference on Cambodia, as well as the Secretary-General of the United Nations.

IN WITNESS WHEREOF the undersigned Plenipotentiaries, being duly authorized thereto, have signed this Agreement.

DONE at Paris this twenty-third day of October, one thousand nine hundred and ninety one.

\section{ANNEX 1 \\ UNTAC mandate}

\section{Section A. General procedure}

1. In accordance with article 6 of the Agreement, UNTAC will exercise the powers necessary to ensure the implementation of this Agreement, including those relating to the organization and conduct of free and fair elections and the relevant aspects of the administration of Cambodia.

2. The following mechanism will be used to resolve all issues relating to the implementation of this Agreement which may arise between the Secretary-General's Special Representative and the Supreme National Council (SNC):

(a) The SNC offers advice to UNTAC, which will comply with this advice provided there is a consensus among the members of the SNC and provided this advice is consistent with the objectives of the present Agreement;

(b) If there is no consensus among the members of the SNC despite every endeavour of its President, H.R.H. Samdech NORODOM SIHANOUK, the President will be entitled to make the decision on what advice to offer to UNTAC, taking fully into account the views expressed in the SNC. UNTAC will comply with the advice provided it is consistent with the objectives of the present Agreement;

(c) If H.R.H. Samdech NORODOM SIHANOUK, President of the SNC, the legitimate representative of Cambodian sovereignty, is not, for whatever reason, in a position to make such a decision, his power of decision will transfer to the Secretary-General's Special Representative. The Special Representative will make the final decision, taking fully into account the views expressed in the $\mathrm{SNC}$;

(d) Any power to act regarding the implementation of this Agreement conferred upon the SNC by the Agreement will be exercised by consensus or, failing such consensus, by its President in accordance with the procedure set out above. In the event that H.R.H. Samdech NORODOM SIHANOUK, President of the SNC, the legitimate representative of Cambodian sovereignty, is not, for whatever reason, in a position to act, his power to act will transfer to the Secretary-General's Special Representative who may take the necessary action;

(e) In all cases, the Secretary-General's Special Representative will determine whether advice or action of the SNC is consistent with the present Agreement. 
3. The Secretary-General's Special Representative or his delegate will attend the meetings of the SNC and of any subsidiary body which might be established by it and give its members all necessary information on the decisions taken by UNTAC.

\section{Section B. Civil administration}

1. In accordance with Article 6 of the Agreement, all administrative agencies, bodies and offices acting in the field of foreign affairs, national defence, finance, public security and information will be placed under the direct control of UNTAC, which will exercise it as necessary to ensure strict neutrality. In this respect, the SecretaryGeneral's Special Representative will determine what is necessary and may issue directives to the above-mentioned administrative agencies, bodies and offices. Such directives may be issued to and will bind all Cambodian Parties.

2. In accordance with article 6 of the Agreement, the Secretary-General's Special Representative, in consultation with the SNC, will determine which other administrative agencies, bodies and offices could directly influence the outcome of elections. These administrative agencies, bodies and offices will be placed under direct supervision or control of UNTAC and will comply with any guidance provided by it.

3. In accordance with Article 6 of the Agreement, the Secretary-General's Special Representative, in consultation with the SNC, will identify which administrative agencies, bodies, and offices could continue to operate in order to ensure normal day-to-day life in Cambodia, if necessary, under such supervision by UNTAC as it considers necessary.

4. In accordance with article 6 of the Agreement, the authority of the SecretaryGeneral's Special Representative will include the power to:

(a) Install in administrative agencies, bodies and offices of all the Cambodian Parties, United Nations personnel who will have unrestricted access to all administrative operations and information;

(b) Require the reassignment or removal of any personnel of such administrative agencies, bodies and offices.

5. (a) On the basis of the information provided in Article I, paragraph 3, of annex 2, the Special Representative of the Secretary-General will determine, after consultation with the Cambodian Parties, those civil police necessary to perform law enforcement in Cambodia. All Cambodian Parties hereby undertake to comply with the determination made by the Special Representative in this regard;

(b) All civil police will operate under UNTAC supervision or control, in order to ensure that law and order are maintained effectively and impartially, and that human rights and fundamental freedoms are fully protected. In consultation with the SNC, UNTAC will supervise other law enforcement and judicial processes throughout Cambodia to the extent necessary to ensure the attainment of these objectives.

6. If the Secretary-General's Special Representative deems it necessary, UNTAC, in consultation with the SNC, will undertake investigations of complaints and allegations 
regarding actions by the existing administrative structures in Cambodia that are inconsistent with or work against the objectives of this comprehensive political settlement. UNTAC will also be empowered to undertake such investigation on its own initiative. UNTAC will take, when necessary, appropriate corrective steps.

\section{Section C. Military functions}

1. UNTAC will supervise, monitor and verify the withdrawal of foreign forces, the cease-fire and related measures in accordance with annex 2 , including:

(a) Verification of the withdrawal from Cambodia of all Categories of foreign forces, advisers and military personnel and their weapons, ammunition and equipment, and their non-return to Cambodia;

(b) Liaison with neighbouring Governments over any developments in or near their territory that could endanger the implementation of this Agreement;

(c) Monitoring the cessation of outside military assistance to all Cambodian Parties;

(d) Locating and confiscating caches of weapons and military supplies throughout the country;

(e) Assisting with clearing mines and undertaking training programmes in mine clearance and a mine awareness programme among the Cambodian people.

2. UNTAC will supervise the regrouping and relocating of all forces to specifically designated cantonment areas on the basis of an operational time-table to be agreed upon, in accordance with annex 2.

3. As the forces enter the cantonments, UNTAC will initiate the process of arms control and reduction specified in annex 2.

4. UNTAC will take necessary steps regarding the phased process of demobilization of the military forces of the parties, in accordance with annex 2.

5. UNTAC will assist, as necessary, the International Committee of the Red Cross in the release of all prisoners of war and civilian internees.

\section{Section D. Elections}

1. UNTAC will organize and conduct the election referred to in Part II of this Agreement in accordance with this section and annex 3.

2. UNTAC may consult with the SNC regarding the organization and conduct of the electoral process.

3. In the exercise of its responsibilities in relation to the electoral process, the specific authority of UNTAC will include the following:

(a) The establishment, in consultation with the SNC, of a system of laws, procedures and administrative measures necessary for the holding of a free and fair election in Cambodia, including the adoption of an electoral law and of a 
code of conduct regulating participation in the election in a manner consistent with respect for human rights and prohibiting coercion or financial inducement in order to influence voter preference;

(b) The suspension or abrogation, in consultation with the SNC, of provisions of existing laws which could defeat the objects and purposes of this Agreement;

(c) The design and implementation of a voter education programme, covering all aspects of the election, to support the election process;

(d) The design and implementation of a system of voter registration, as a first phase of the electoral process, to ensure that eligible voters have the opportunity to register, and the subsequent preparation of verified voter registration lists;

(e) The design and implementation of a system of registration of political parties and lists of candidates;

(f) Ensuring fair access to the media, including press, television and radio, for all political parties contesting in the election;

(g) The adoption and implementation of measures to monitor and facilitate the participation off Cambodians in the elections, the political campaign, and the balloting procedures;

(h) The design and implementation of a system of balloting and polling, to ensure that registered voters have the opportunity to vote;

(i) The establishment, in consultation with the SNC, of co-ordinated arrangements to facilitate the presence of foreign observers wishing to observe the campaign and voting;

(j) Overall direction of polling and the vote count;

(k) The identification and investigation of complaints of electoral irregularities, and the taking of appropriate corrective action;

(1) Determining whether or not the election was free and fair and, if so, certification of the list of persons duly elected.

4. In carrying out its responsibilities under the present section, UNTAC will establish a system of safeguards to assist it in ensuring the absence of fraud during the electoral process, including arrangements for Cambodian representatives to observe the registration and polling procedures and the provision of an UNTAC mechanism for hearing and deciding complaints.

5. The timetable for the various phases of the electoral process will be determined by UNTAC, in consultation with the SNC as provided in paragraph 2 of this section. The duration of the electoral process will not exceed nine months from the commencement of voter registration.

6. In organizing and conducting the electoral process, UNTAC will make every effort to ensure that the system and procedures adopted are absolutely impartial, while the operational arrangements are as administratively simple and efficient as possible. 


\section{Section E. Human rights}

In accordance with article 16, UNTAC will make provisions for:

(a) The development and implementation of a programme of human rights education to promote respect for and understanding of human rights;

(b) General human rights oversight during the transitional period;

(c) The investigation of human rights complaints, and, where appropriate, corrective action.

\section{ANNEX 2 \\ Withdrawal, cease-fire and related measures}

\section{Article I \\ Cease-fire}

1. All Cambodian Parties (hereinafter referred to as "the Parties") agree to observe a comprehensive cease-fire on land and water and in the air. This cease-fire will be implemented in two phases. During the first phase, the cease-fire will be observed with the assistance of the Secretary-General of the United Nations through his good offices. During the second phase, which should commence as soon as possible, the cease-fire will be supervised, monitored and verified by UNTAC. The Commander of the military component of UNTAC, in consultation with the Parties, shall determine the exact time and date at which the second phase will commence. This date will be set at least four weeks in advance of its coming into effect.

2. The Parties undertake that, upon the signing of this Agreement, they will observe a cease-fire and will order their armed forces immediately to disengage and refrain from all hostilities and any deployment, movement or action that would extend the territory they control or that might lead to a resumption of fighting, pending the commencement of the second phase. "Forces" are agreed to include all regular, provincial, district, paramilitary, and other auxiliary forces. During the first phase, the Secretary-General of the United Nations will provide his good offices to the Parties to assist them in its observance. The Parties undertake to co-operate with the Secretary-General or his representatives in the exercise of his good offices in this regard.

3. The Parties agree that, immediately upon the signing of this Agreement, the following information will be provided to the United Nations:

(a) Total strength of their forces, organization, precise number and location of deployments inside and outside Cambodia. The deployment will be depicted on a map marked with locations of all troop positions, occupied or unoccupied, including staging camps, supply bases and supply routes; 
(b) Comprehensive lists of arms, ammunition and equipment held by their forces, and the exact locations at which those arms, ammunition and equipment are deployed;

(c) Detailed record of their mine-fields, including types and characteristics of mines laid and information of booby traps used by them together with any information available to them about mine-fields laid or booby traps used by the other Parties;

(d) Total strength of their police forces, organization, precise numbers and locations of deployments, as well as comprehensive lists of their arms, ammunition and equipment, and the exact locations at which those arms, ammunition and equipment are deployed.

4. Immediately upon his arrival in Cambodia, and not later than four weeks before the beginning of the second phase, the Commander of the military component of UNTAC will, in consultation with the Parties, finalize UNTAC's plan for the regroupment and cantonment of the forces of the Parties and for the storage of their arms, ammunition and equipment, in accordance with article III of this annex. This plan will include the designation of regroupment and cantonment areas, as well as an agreed timetable. The cantonment areas will be established at battalion size or larger.

5. The Parties agree to take steps to inform their forces at least two weeks before the beginning of the second phase, using all possible means of communication, about the agreed date and time of the beginning of the second phase, about the agreed plan for the regroupment and cantonment of their forces and for the storage of their arms, ammunition and equipment and, in particular, about the exact locations of the regroupment areas to which their forces are to report. Such information will continue to be disseminated for a period of four weeks after the beginning of the second phase.

6. The Parties shall scrupulously observe the cease-fire and will not resume any hostilities by land, water or air. The commanders of their armed forces will ensure that all troops under their command remain on their respective positions, pending their movement to the designated regroupment areas, and refrain from all hostilities and from any deployment or movement or action which would extend the territory they control or which might lead to a resumption of fighting.

\section{Article II}

\section{Liaison system and Mixed Military Working Group}

A Mixed Military Working Group (MMWG) will be established with a view to resolving any problems that may arise in the observance of the cease-fire. It will be chaired by the most senior United Nations military officer in Cambodia or his representative. Each Party agrees to designate an officer of the rank of brigadier or equivalent to serve on the MMWG. Its composition, method of operation and meeting places will be determined by the most senior United Nations military officer in consultation with the Parties. Similar liaison arrangements will be made at lower military command levels to resolve practical problems on the ground. 


\section{Article III \\ Regroupment and cantonment of the forces of the Parties and storage of their arms, ammunition and equipment}

1. In accordance with the operational timetable referred to in paragraph 4 of article I of the present annex, all forces of the Parties that are not already in designated cantonment areas will report to designated regroupment areas, which will be established and operated by the military component of UNTAC. These regroupment areas will be established and operational not later than one week prior to the date of the beginning of the second phase. The Parties agree to arrange for all their forces, with all their arms, ammunition and equipment, to report to regroupment areas within two weeks after the beginning of the second phase. All personnel who have reported to the regroupment areas will thereafter be escorted by personnel of the military component of UNTAC, with their arms, ammunition and equipment, to designated cantonment areas. All Parties agree to ensure that personnel reporting to the regroupment areas will be able to do so in full safety and without any hindrance.

2. On the basis of the information provided in accordance with paragraph 3 of article I of the present annex, UNTAC will confirm that the regroupment and cantonment processes have been completed in accordance with the plan referred to in paragraph 4 or article I of this annex. UNTAC will endeavour to complete these processes within four weeks from the date of the beginning of the second phase. On the completion of regroupment of all forces and of their movement to cantonment areas, respectively, the Commander of the military component of UNTAC will so inform each of the four Parties.

3. The Parties agree that, as their forces enter the designated cantonment areas, their personnel will be instructed by their commanders to immediately hand over all their arms, ammunition and equipment to UNTAC for storage in the custody of UNTAC.

4. UNTAC will check the arms, ammunition and equipment handed over to it against the lists referred to in paragraph 3.b of article I of this annex, in order to verify that all the arms, ammunition and equipment in the possession of the Parties have been placed under its custody.

\section{Article IV}

\section{Resupply of forces during cantonment}

The military component of UNTAC will supervise the resupply of all forces of the Parties during the regroupment and cantonment processes. Such resupply will be confined to items of a non-lethal nature such as food, water, clothing and medical supplies as well as provision of medical care. 


\section{Article $V$ \\ Ultimate disposition of the forces of the Parties and of their arms, ammunition and equipment}

1. In order to reinforce the objectives of a comprehensive political settlement, minimize the risks of a return to warfare, stabilize the security situation and build confidence among the Parties to the conflict, all Parties agree to undertake a phased and balanced process of demobilization of at least 70 per cent of their military forces. This process shall be undertaken in accordance with a detailed plan to be drawn up by UNTAC on the basis of the information provided under Article I of this annex and in consultation with the Parties. It should be completed prior to the end of the process of registration for the elections and on a date to be determined by the special Representative of the Secretary-General.

2. The Cambodian Parties hereby commit themselves to demobilize all their remaining forces before or shortly after the elections and, to the extent that full demobilization is unattainable, to respect and abide by whatever decision the newly elected government that emerges in accordance with Article 12 of this Agreement takes with regard to the incorporation of parts or all of those forces into a new national army. Upon completion of the demobilization referred to in paragraph 1, the Cambodian Parties and the Special Representative of the Secretary-General shall undertake a review regarding the final disposition of the forces remaining in the cantonments, with a view to determining which of the following shall apply:

(a) If the Parties agree to proceed with the demobilization of all or some of the forces remaining in the cantonments, preferably prior to or otherwise shortly after the elections, the Special Representative shall prepare a time-table for so doing, in consultation with them.

(b) Should total demobilization of all of the residual forces before or shortly after the elections not be possible, the Parties hereby undertake to make available all of their forces remaining in cantonments to the newly elected government that emerges in accordance with Article 12 of this Agreement, for consideration for incorporation into a new national army. They further agree that any such forces which are not incorporated into the new national army will be demobilized forthwith according to a plan to be prepared by the Special Representative. With regard to the ultimate disposition of the remaining forces and all the arms, ammunition and equipment, UNTAC, as its withdraws from Cambodia, shall retain such authority as is necessary to ensure an orderly transfer to the newly elected government of those responsibilities it has exercised during the transitional period.

3. UNTAC will assist, as required, with the reintegration into civilian life of the forces demobilized prior to the elections.

4. (a) UNTAC will control and guard all the arms, ammunition and equipment of the Parties throughout the transitional period; 
(b) As the cantoned forces are demobilized in accordance with paragraph 1 above, there will be a parallel reduction by UNTAC of the arms, ammunition and equipment stored on site in the cantonment areas. For the forces remaining in the cantonment areas, access to their arms, ammunition and equipment shall only be on the basis of the explicit authorization of the Special Representative of the Secretary-General;

(c) If there is a further demobilization of the military forces in accordance with paragraph 2. a) above, there will be commensurate reduction by UNTAC of the arms, ammunition and equipment stored on site in the cantonment areas;

(d) The ultimate disposition of all arms, ammunition and equipment will be determined by the government that emerges through the free and fair elections in accordance with article 12 of this Agreement.

\section{Article VI}

\section{Verification of withdrawal from Cambodia and non-return of all categories of foreign forces}

1. UNTAC shall be provided, no later than two weeks before the commencement of the second phase of the cease-fire, with detailed information in writing regarding the withdrawal of foreign forces. This information shall include the following elements:

(a) Total strength of these forces and their organization and deployment;

(b) Comprehensive lists of arms, ammunition and equipment held by these forces, and their exact locations;

(c) Withdrawal plan (already implemented or to be implemented), including withdrawal routes, border crossing points and time of departure from Cambodia.

2. On the basis of the information provided in accordance with paragraph 1 above, UNTAC will undertake an investigation in the manner it deems appropriate. The Party providing the information will be required to make personnel available to accompany UNTAC investigators.

3. Upon confirmation of the presence of any foreign forces, UNTAC will immediately deploy military personnel with the foreign forces and accompany them until they have withdrawn from Cambodian territory. UNTAC will also establish checkpoints on withdrawal routes, border crossing points and airfields to verify the withdrawal and ensure the non-return of all categories of foreign forces.

4. The Mixed Military Working Group (MMWG) provided for in article II of this annex will assist UNTAC in fulfilling the above-mentioned tasks.

\section{Article VII}

\section{Cessation of outside military assistance to all Cambodian Parties}

1. All Parties undertake, from the time of the signing of this Agreement, not to obtain 
or seek any outside military assistance, including weapons, ammunition and military equipment from outside sources.

2. The Signatories whose territory is adjacent to Cambodia, namely, the Governments of the Lao People's Democratic Republic, the Kingdom of Thailand and the Socialist Republic of Vietnam, undertake to:

(a) Prevent the territories of their respective States, including land territory, territorial sea and air space, from being used for the purpose of providing any form of military assistance to any of the Cambodian Parties. Resupply of such items as food, water, clothing and medical supplies through their territories will be allowed, but shall, without prejudice to the provisions of sub-paragraph (c) below, be subject to UNTAC supervision upon arrival in Cambodia;

(b) Provide written confirmation to the Commander of the military component of UNTAC, not later than four weeks after the second phase of the cease-fire begins, that no forces, arms, ammunition or military equipment of any of the Cambodian Parties are present on their territories;

(c) Receive an UNTAC liaison officer in each of their capitals and designate an officer of the rank of colonel or equivalent, not later than four weeks after the beginning of the second phase of the cease-fire, in order to assist UNTAC in investigating, with due respect for their sovereignty, any complaints that activities are taking place on their territories that are contrary to the provisions of the comprehensive political settlement.

3. To enable UNTAC to monitor the cessation of outside assistance to all Cambodian Parties, the Parties agree that, upon signature of this Agreement, they will provide to UNTAC any information available to them about the routes and means by which military assistance, including weapons, ammunition and military equipment, have been supplied to any of the Parties. Immediately after the second phase of the cease-fire begins, UNTAC will take the following practical measures:

(a) Establish check-points along the routes and at selected locations along the Cambodian side of the border and at airfields inside Cambodia;

(b) Patrol the coastal and inland waterways of Cambodia;

(c) Maintain mobile teams at strategic locations within Cambodia to patrol and investigate allegations of supply of arms to any of the Parties.

\section{Article VIII}

\section{Caches of weapons and military supplies}

1. In order to stabilize the security situation, build confidence and reduce arms and military supplies throughout Cambodia, each Party agrees to provide to the Commander of the military component of UNTAC, before a date to be determined by him, all information at its disposal, including marked maps, about known or suspected caches of weapons and military supplies throughout Cambodia. 
2. On the basis of information received, the military component of UNTAC shall, after the date referred to in paragraph 1 , deploy verification teams to investigate each report and destroy each cache found.

\section{Article IX}

\section{Unexploded ordnance devices}

1. Soon after arrival in Cambodia, the military component of UNTAC shall ensure, as a first step, that all known mine-fields are clearly marked.

2. The Parties agree that, after completion of the regroupment and cantonment processes in accordance with Article III of the present annex, they will make available mine-clearing teams which, under the supervision and control of UNTAC military personnel, will leave the cantonment areas in order to assist in removing, disarming or deactivating remaining unexploded ordnance devices. Those mines or objects which cannot be removed, disarmed or deactivated will be clearly marked in accordance with a system to be devised by the military component of UNTAC.

3. UNTAC shall:

(a) Conduct a mass public education programme in the recognition and avoidance of explosive devices;

(b) Train Cambodian volunteers to dispose of unexploded ordnance devices;

(c) Provide emergency first-aid training to Cambodian volunteers.

\section{Article X}

\section{Investigation of violations}

1. After the beginning of the second phase, upon receipt of any information or complaint from one of the Parties relating to a possible case of non-compliance with any of the provisions of the present annex or related provisions, UNTAC will undertake an investigation in the manner which it deems appropriate. Where the investigation takes place in response to a complaint by one of the Parties, that Party will be required to make personnel available to accompany the UNTAC investigators. The results of such investigation will be conveyed by UNTAC to the complaining Party and the Party complained against, and if necessary to the SNC.

2. UNTAC will also carry out investigations on its own initiative in other cases when it has reason to believe or suspect that a violation of this annex or related provisions may be taking place.

\section{Article XI}

\section{Release of prisoners of war}

The military component of UNTAC will provide assistance as required to the 
International Committee of the Red Cross in the latter's discharge of its functions relating to the release of prisoners of war.

\title{
Article XII
}

\section{Repatriation and resettlement of displaced Cambodians}

The military component of UNTAC will provide assistance as necessary in the repatriation of Cambodian refugees and displaced persons carried out in accordance with articles 19 and 20 of this Agreement, in particular in the clearing of mines from repatriation routes, reception centres and resettlement areas, as well as in the protection of the reception centres.

\author{
ANNEX 3 \\ Elections \\ [...] \\ ANNEX 4 \\ Repatriation of Cambodian refugees and displaced persons
}

\section{PART I}

\section{INTRODUCTION}

1. As part of the comprehensive political settlement, every assistance will need to be given to Cambodian refugees and displaced persons as well as to countries of temporary refuge and the country of origin in order to facilitate the voluntary return of all Cambodian refugees and displaced persons in a peaceful and orderly manner. It must also be ensured that there would be no residual problems for the countries of temporary refuge. The country of origin with responsibility towards its own people will accept their return as conditions become conducive.

\section{PART II}

\section{CONDITIONS CONDUCIVE TO THE RETURN OF REFUGEES AND DISPLACED PERSONS}

2. The task of rebuilding the Cambodian nation will require the hamessing of all its human and natural resources. To this end, the return to the place of their choice of Cambodians from their temporary refuge and elsewhere outside their country of origin will make a major contribution.

3. Every effort should be made to ensure that the conditions which have led to a large number of Cambodian refugees and displaced persons seeking refuge in other 
countries should not recur. Nevertheless, some Cambodian refugees and displaced persons will wish and be able to return spontaneously to their homeland.

4. There must be full respect for the human rights and fundamental freedoms of all Cambodians, including those of the repatriated refugees and displaced persons, in recognition of their entitlement to live in peace and security, free from intimidation and coercion of any kind. These rights would include, inter alia, freedom of movement within Cambodia, the choice of domicile and employment, and the right to property.

5. In accordance with the comprehensive political settlement, every effort should be made to create concurrently in Cambodia political, economic and social conditions conducive to the return and harmonious integration of the Cambodian refugees and displaced persons.

6. With a view to ensuring that refugees and displaced persons participate in the elections, mass repatriation should commence and be completed as soon as possible, taking into account all the political, humanitarian, logistical, technical and socioeconomic factors involved, and with the co-operation of the SNC.

7. Repatriation of Cambodian refugees and displaced persons should be voluntary and their decision should be taken in full possession of the facts. Choice of destination within Cambodia should be that of the individual. The unity of the family must be preserved.

\section{PART III}

\section{OPERATIONAL FACTORS}

8. Consistent with respect for principles of national sovereignty in the countries of temporary refuge and origin, and in close co-operation with the countries of temporary refuge and origin, full access by the Office of the United Nations High Commissioner for Refugees (UNHCR), ICRC and other relevant international agencies should be guaranteed to all Cambodian refugees and displaced persons, with a view to the agencies undertaking the census, tracing, medical assistance, food distribution and other activities vital to the discharge of their mandate and operational responsibilities; such access should also be provided in Cambodia to enable the relevant international organizations to carry out their traditional monitoring as well as operational responsibilities.

9. In the context of the comprehensive political settlement, the signatories note with satisfaction that the Secretary-General of the United Nations has entrusted UNHCR with the role of leadership and co-ordination among intergovernmental agencies assisting with the repatriation and relief of Cambodian refugees and displaced persons. The Signatories look to all non-governmental organizations to co-ordinate as much as possible their work for the Cambodian refugees and displaced persons with that of UNHCR.

10. The SNC, the Governments of the countries in which the Cambodian refugees and displaced persons have sought temporary refuge, and the countries which contribute to the repatriation and integration effort, will wish to monitor closely and facilitate 
the repatriation of the returnees. An ad hoc consultative body should be established for a limited term for these purposes. The UNHCR, the ICRC, and other international agencies as appropriate, as well as UNTAC, would be invited to join as full participants.

11. Adequately monitored short-term repatriation assistance should be provided on an impartial basis to enable the families and individuals returning to Cambodia to establish their lives and livelihoods harmoniously in their society. These interim measures would be phased out and replaced in the longer term by the reconstruction programme.

12. Those responsible for organizing and supervising the repatriation operation will need to ensure that conditions of security are created for the movement of the refugees and displaced persons. In this respect, it is imperative that appropriate border crossing points and routes be designated and cleared of mines and other hazards.

13. The international community should contribute generously to the financial requirements of the repatriation operation.

\section{ANNEX 5}

\section{Principles for a new constitution for Cambodia}

$$
[\ldots]
$$

\section{III - AGREEMENT CONCERNING THE SOVEREIGNTY, INDEPENDENCE, TERRITORIAL INTEGRITY AND INVIOLABILITY, NEUTRALITY AND NATIONAL UNITY OF CAMBODIA, PARIS 31 OCTOBER 1991}

Australia, Brunei Darussalam, Cambodia, Canada, the People's Republic of China, the French Republic, the Republic of India, the Republic of Indonesia, Japan, the Lao People's Democratic Republic, Malaysia, the Republic of the Philippines, the Republic of Singapore, the Kingdom of Thailand, the Union of Soviet Socialist Republics, the United Kingdom of Great Britain and Northern Ireland, the United States of America, the Socialist Republic of Vietnam and the Socialist Federal Republic of Yugoslavia,

In the presence of the Secretary-General of the United Nations,

Convinced that a comprehensive political settlement for Cambodia is essential for the long-term objective of maintaining peace and security in South-East Asia,

Recalling their obligations under the Charter of the United Nations and other rules of international law,

Considering that full observance of the principles of non-interference and nonintervention in the internal end external affairs of States is of the greatest importance for the maintenance of international peace and security,

Reaffirming the inalienable right of States freely to determine their own political, economic, cultural and social systems in accordance with the will of their peoples, without outside interference, subversion, coercion or threat in any form whatsoever, 
Desiring to promote respect for and observance of human rights and fundamental freedoms in conformity with the Charter of the United Nations and other relevant international instruments,

Have agreed as follows:

\section{Article 1}

1. Cambodia hereby solemnly undertakes to maintain, preserve and defend its sovereignty, independence, territorial integrity and inviolability, neutrality, and national unity; the perpetual neutrality of Cambodia shall be proclaimed and enshrined in the Cambodian constitution to be adopted after free and fair elections.

2. To this end, Cambodia undertakes:

(a) To refrain from any action that might impair the sovereignty, independence and territorial integrity and inviolability of other States;

(b) To refrain from entering into any military alliances or other military agreements with other States that would be inconsistent with its neutrality, without prejudice to Cambodia's right to acquire the necessary military equipment, arms, munitions and assistance to enable it to exercise its inherent right of self-defence and to maintain law and order;

(c) To refrain from interference in any form whatsoever, whether direct or indirect, in the internal affairs of other States;

(d) To terminate treaties and agreements that are incompatible with its sovereignty, independence, territorial integrity and inviolability, neutrality, and national unity;

(e) To refrain from the threat or use of force against the territorial integrity or political independence of any State, or in any other manner inconsistent with the purposes of the United Nations;

(f) To settle all disputes with other States by peaceful means;

(g) To refrain from using its territory or the territories of other States to impair the sovereignty, independence, and territorial integrity and inviolability of other States;

(h) To refrain from permitting the introduction or stationing of foreign forces, including military personnel, in any form whatsoever, in Cambodia, and to prevent the establishment or maintenance of foreign military bases, strong points or facilities in Cambodia, except pursuant to United Nations authorization for the implementation of the comprehensive political settlement.

\section{Article 2}

1. The other parties to this Agreement hereby solemnly undertake to recognize and to respect in every way the sovereignty, independence, territorial integrity and inviolability, neutrality and national unity of Cambodia. 
2. To this end, they undertake:

(a) To refrain from entering into any military alliances or other military agreements with Cambodia that would be inconsistent with Cambodia's neutrality, without prejudice to Cambodia's right to acquire the necessary military equipment, arms, munitions and assistance to enable it to exercise its inherent right of self-defence and to maintain law and order;

(b) To refrain from interference in any form whatsoever, whether direct or indirect, in the internal affairs of Cambodia;

(c) To refrain from the threat or use of force against the territorial integrity or political independence of Cambodia, or in any other manner inconsistent with the purposes of the United Nations;

(d) To settle all disputes with Cambodia by peaceful means;

(e) To refrain from using their territories or the territories of other States to impair the sovereignty, independence, territorial integrity and inviolability, neutrality and national unity of Cambodia;

(f) To refrain from using the territory of Cambodia to impair the sovereignty, independence and territorial integrity and inviolability of other States;

(g) To refrain from the introduction or stationing of foreign forces, including military personnel, in any form whatsoever, in Cambodia and from establishing or maintaining military bases, strong points or facilities in Cambodia, except pursuant to United Nations authorization for the implementation of the comprehensive political settlement.

\section{Article 3}

1. All persons in Cambodia shall enjoy the rights and freedoms embodied in the Universal Declaration of Human Rights and other relevant international human rights instruments.

2. To this end,

(a) Cambodia undertakes:

- to ensure respect for and observance of human rights and fundamental freedoms in Cambodia;

- to support the right of all Cambodian citizens to undertake activities that would promote and protect human rights and fundamental freedoms;

- to take effective measures to ensure that the policies and practices of the past shall never be allowed to return;

- to adhere to relevant international human rights instruments;

(b) The other parties to this Agreement undertake to promote and encourage respect for and observance of human rights and fundamental freedoms in Cambodia as embodied in the relevant international instruments in order, in particular, to prevent the recurrence of human rights abuses. 
3. The United Nations Commission on Human Rights should continue to monitor closely the human rights situation in Cambodia, including, if necessary, by the appointment of a Special Rapporteur who would report his findings annually to the Commission and to the General Assembly.

\section{Article 4}

The parties to this Agreement call upon all other States to recognize and respect in every way the sovereignty, independence, territorial integrity and inviolability, neutrality and national unity of Cambodia and to refrain from any action inconsistent with these principles or with other provisions of this Agreement.

\section{Article 5}

1. In the event of a violation or threat of violation of the sovereignty, independence, territorial integrity and inviolability, neutrality or national unity of Cambodia, or of any of the other commitments herein, the parties to this Agreement undertake to consult immediately with a view to adopting all appropriate steps to ensure respect for these commitments and resolving any such violations through peaceful means.

2. Such steps may include, inter alia, reference of the matter to the Security Council of the United Nations or recourse to the means for the peaceful settlement of disputes referred to in Article 33 of the Charter of the United Nations.

3. The parties to this Agreement may also call upon the assistance of the cochairmen of the Paris Conference on Cambodia.

4. In the event of serious violations of human rights in Cambodia, they will call upon the competent organs of the United Nations to take such other steps as are appropriate for the prevention and suppression of such violations in accordance with the relevant international instruments.

\section{Article 6}

This Agreement shall enter into force upon signature.

\section{Article 7}

This Agreement shall remain open for accession by all States. The instruments of accession shall be deposited with the Governments of the French Republic and the Republic of Indonesia. For each State acceding to this Agreement, it shall enter into force on the date of deposit of its instrument of accession.

\section{Article 8}

The original of this Agreement, of which the Chinese, English, French, Khmer and Russian texts are equally authentic, shall be deposited with the Governments of the French Republic and the Republic of Indonesia, which shall transmit certified true copies to the Governments of the other States participating in the Paris Conference on Cambodia and to the Secretary-General of the United Nations. 
IN WITNESS WHEREOF the undersigned plenipotentiaries, being duly authorized thereto, have signed this Agreement.

DONE at Paris this thirty first day of October, one thousand nine hundred and ninety one.

\section{IV - DECLARATION ON THE REHABILITATION AND RECONSTRUC- TION OF CAMBODIA}

1. The primary objective of the reconstruction of Cambodia should be the advancement of the Cambodian nation and people, without discrimination or prejudice, and with full respect for human rights and fundamental freedom for all. The achievement of this objective requires the full implementation of the comprehensive political settlement.

2. The main responsibility for deciding Cambodia's reconstruction needs and plans should rest with the Cambodian people and the government formed after free and fair elections. No attempt should be made to impose a development strategy on Cambodia from any outside source or deter potential donors from contributing to the reconstruction of Cambodia.

3. International, regional and bilateral assistance to Cambodia should be co-ordinated as much as possible, complement and supplement local resources and be made available impartially with full regard for Cambodia's sovereignty, priorities, institutional means and absorptive capacity.

4. In the context of the reconstruction effort, economic aid should benefit all areas of Cambodia, especially the more disadvantaged, and reach all levels of society.

5. The implementation of an international aid effort would have to be phased in over a period that realistically acknowledges both political and technical imperatives. It would also necessitate a significant degree of co-operation between the future Cambodian Government and bilateral, regional and international contributors.

6. An important role will be played in rehabilitation and reconstruction by the United Nations system. The launching of an international reconstruction plan and an appeal for contributions should take place at an appropriate time, so as to ensure its success.

7. No effective programme of national reconstruction can be initiated without detailed assessments of Cambodia's human, natural and other economic assets. It will be necessary for a census to be conducted, developmental priorities identified, and the availability of resources, internal and external, determined.

To this end there will be scope for sending to Cambodia fact-finding missions from the United Nations system, international financial institutions and other agencies, with the consent of the future Cambodian Government.

8. With the achievement of the comprehensive political settlement, it is now possible and desirable to initiate a process of rehabilitation, addressing immediate needs, and to lay the groundwork for the preparation of medium- and long-term reconstruction plans. 
9. For this period of rehabilitation, the United Nations Secretary-General is requested to help co-ordinate the programme guided by a person appointed for this purpose.

10. In this rehabilitation phase, particular attention will need to be given to food security, health, housing, training, education, the transport network and the restoration of Cambodia's existing basic infrastructure and public utilities.

11. The implementation of a longer-term international development plan for reconstruction should await the formation of a government following the elections and the determination and adoption of its own policies and priorities.

12. This reconstruction phase should promote Cambodian entrepreneurship and make use of the private sector, among other sectors, to help advance self-sustaining economic growth. It would also benefit from regional approaches, involving, inter alia, institutions such as the Economic and Social Commission for Asia and the Pacific (ESCAP) and the Mekong Committee, and Governments within the region; and from participation by non-governmental organizations.

13. In order to harmonize and monitor the contributions that will be made by the international community to the reconstruction of Cambodia after the formation of a government following the elections, a consultative body, to be called the International Committee on the Reconstruction of Cambodia (ICORC), should be set up at an appropriate time and be open to potential donors and other relevant parties. The United Nations Secretary-General is requested to make special arrangements for the United Nations system to support ICORC in its work, notably in ensuring a smooth transition from the rehabilitation to reconstruction phases. 